Article

\title{
An Investigation to Conversations to Identify the Language Style in a Movie: A Study on Sociolinguistics
}

\author{
Ribka Yunita Turnip ${ }^{1}$, Herman ${ }^{1}$, Partohap Saut Raja Sihombing ${ }^{1}$, Ridwin Purba ${ }^{2, *}$ \\ ${ }^{1}$ Department of English Education, Universitas HKBP Nommensen, Medan, Indonesia \\ ${ }^{2}$ Department of English Education, Universitas Simalungun, Pematangsiantar, Indonesia \\ *Correspondence: nridwin@yahoo.com
}

How to cite this paper: Yunita Turnip, R., Herman, Saut Raja Sihombing, P., \& Purba, R. (2021). An Investigation to Conversations to Identify the Language Style in a Movie: A Study on Sociolinguistics. Universal Journal of Literature and Linguistics, 1(1), 1-9. Retrieved from https://www.scipublications.com/journal/index.php/ujll/article/view/152

Received: August 2, 2021

Accepted: October 4, 2021

Published: October 5, 2021

Copyright: (c) 2021 by the authors. Submitted for possible open access publication under the terms and conditions of the Creative Commons Attribution (CC BY) license (http://creativecommons.org/licenses /by/4.0/).

\begin{abstract}
The aims of this investigation will be to describe the language style based on Spider-Martin Man's Joos: far from home films and to identify the dominant language styles of the movie "Spider-Man: far from home." The analyzes are based on Martin Joo's theory's five types of linguistic style: frozen, formal, consultative, casual, and intimate. Qualitative research design was used in the research. Content or document analysis was used by researchers. The information is gathered by watching the film and the conversation containing the communication language is detected. Then classify according to the language styles found in the film and find the main kinds of language. The results of this research are as follows in the Spider-Man section: Far From the Home." These five language-style types are Frozen made up of two data $(6,7 \%)$, formal three (10\%), consultants of six data $(20 \%)$, casual eleven $(36,7 \%)$ and intimacy consisting of eight data. The following are the types of language-styles (26,6 percent). The Casual style is the most dominant type than other types from the result of the percentage. In last place, the style is frozen.
\end{abstract}

Keywords: conversation; sociolinguistics; language style; literature

\section{Introduction}

Language is a fundamental tool for communicating with others. Our ideas and knowledge can be shared in language. People interact with others by means of a language and perform daily social activities. For this reason, in this lifetime, the role of language is very important, as language is necessary to express our emotions, thoughts and feelings. Language is a means of communication, by language we can talk to our friends, express our thoughts, our feelings [8]. Language uses sounds, gestures and signals with patterns and meanings. Goldstein [6] says that language as a communication system uses sounds or symbols that allow us to express our sensations, thoughts, ideas and experiences [13]. It is clear from the definition that people use language to express their ideas, feelings, ideas, and the fact that we use it every day to communicate every day.

The whole world is full of languages. Their languages are Indonesian, Korean, Mandarin and English. English is a global language from many languages throughout the world used as a means for communication between language nations. Mappiasse and Johari said English is one of the languages most widely spoken in today's world [12]. English plays a major role in communicating and English can also speed up a nation's science and technological development. From elementary school through university, English has begun learning in Indonesia. The English component is taught in linguistic science.

Communication means a process of exchanging ideas between people for information or anything else. Communications are an important aspect in our day-to-day activities [7]. As a person, it is not possible for people to be separated from social life because people are social and need help from others. The study of language related to society is 
called sociolinguistics with two words: social or social and linguistic means language science. Fishman in Wardhaugh states that sociolinguistics ought to include everything from "who speaks (or writes) whom, when and for what end" - which language (or what language variety) [21]. In communication, communication is exchanged and quality information is also provided.

The language of communication users is different, like the language they use in meetings is more informal than when they talk to their friend every day. Some words play an active role in certain phrases in the language as well. They are verb that have an active role to play in understanding a significance. A language that is different from the speaker used during communication. It depends on certain aspects, such as who you talk to when you talk to and where you talk. The language style may be used by the speaker. The language style can be divided into language, dialect, accent, jargon, slang, style, and register according to their use. Further The claim that the language style can describe personality, mindset and human condition is according to [11]. The human condition can create the language style of humans. It will be different from casual conditions if someone has a normal state. This happens in films and novels as we look at the perspective of language styles. The word "styles" is the natural way, custom and preferred way for an individual to adsorb, process and retain new information [22].

Language variation is a language phenomenon that occurs in speech community. According to [15], language style is a variety of language caused by differences in language situations or differences in the relationship between speakers (writers) and listeners (readers). Everyone has a different way of speaking, even though the topic of conversation is the same but it does not guarantee that the language style used is the same when communication. This is what causes the loss of the meaning of speech and understanding when communicating. The language-style is the choice among the other language alternatives [5]. It refers to the way the same information is transmitted by different words and by different language variations that are used in different situations and requirements.

Holmes says that variation is a general term which, for social reasons, includes various accents, different styles, dialects, and even language contrasts [9]. The social and formal context of the speech depends on each greeting. The way people talk is not only variable by their original and societal dialects but also by context [19]. The distinctive way people speak in a particular situation is known as style. This type of style difference or language variation has to do with social factors that appear in a person's speech. As we know every language around the world and even regions have differences. Everyone has a different style when expressing his thoughts. The choice of style depends on several aspects, which are possible replaced by the term social factors.

Speaking style is the form of the language used by speakers, and is marked [16]. This talk is divided in five forms by Joos. They are frozen, formal, consulting, casual and intimate style. They are intimate. All types have functions such as the frozen type used for formal events such as ceremonies, speeches or government official meetings, consultations, which are generally used at school or college, which are relaxed and usually intimate when speaking to close family members. The style changes depend on what environment the communication is served in, according to [1]; the upper-class language of the environment is different from that of a lesser-class environment. It is also a stratification environment, for example, of age, gender, and other social conditions. The use of the language style depends on the linguistic civilization as a State.

The speech of a person is influenced by the context of the associations [19]. It consists of who can hear and where we speak and how we feel about the other person with whom we speak. Social elements like participants, subjects, settings and functions. Literature can express the application of the language style. In songs, poems, films, and others the literature can be found. Film is one of the literary works people frequently watch for information. Films are also known as visual communication that tells stories or gives information using images and sounds (helping people to learn). The film was considered as an 
important form of art, a root of mode entertainment and a source of education to citizens that have learned and received education from films because of a lot of massages which implied and which have been found there [4]. In addition, values like moral values, educational values and other values have also been inserted. We can watch from the internet and television. Movie is now developing very rapidly, especially in Indonesia. Cinemas that made from United States, it called Hollywood movie. The Hollywood movie is very popular among teenagers and the general public: End Game, Wild Child, Batman etc.

There are many films about the linguistic style. A film called "Spider-Man:Far From Home" is taken for purpose in this research. This film is therefore an interesting object which can be used for this thesis. Multiple language styles are often used in this film. The purpose of this study is to identify the language style used in "Spider-Man: Far From Home" and the language used in the movie "Spider-Man: Far From Home." This research can therefore be a comprehensive one, as the use of linguistic styles in communication that are always inappropriate and often used by all is integrated into this research. [16] advocated language theory, divided it in styles like frozen fashion, formal fashion, consulting style, casual style, and intimate style.

The dialog below is an example of the way movie characters and verbs from the nouns are made in this dialog.

\begin{tabular}{|l|l|}
\hline Peter Parker & : Hey, man. Are you sure you're good? \\
\hline Ned Leeds & : Oh, dude. I'm fine \\
\hline
\end{tabular}

The sentence above is a casual style, According to Joos (1967) in Rahardian (2016:1), language style means the form of language used by the speaker and its characteristics, because this style of communication is usually mostly casual conversations that are used when communicating with friends. Casual style is a style used for conversation when a student has a conversation, relaxed or normal, which suits conversation with friends, or at times with family members, such as those outside the school. Also casual stylistic, instead of addressing each other with a name and last name, is characterized by the use of the first name or even the nickname. In addition to slang use, pronunciation is quick and often slurred. Here, the conversation between Peter and Ned above is about Peter's concern about Ned's situation. Peter asks his friend if Ned is feeling well. In the conversation between Peter and Ned, the researchers found that the conversation used slang words commonly used by people who are familiar with each other. For example the slang words used in the conversation is DudeAnd here Peter calling Ned used Man or nickname.

The researchers showed a further study using the same but distinct theory. Raharjo [17], the Sunan Ampel Islamic State University students, researched which language is used in the LINE conversation." He used Joos' theory in his thesis to analyze the types of linguistic styles, related with Lackoff's theory that linguistic styling used between man and woman to attract attention, influence, and persuade others to speak in LINE. The one most used in conversation by women and men, 169 of them casual, as the casual style has simple structure and allows people to use the language with their friends.

Based on the reasons above, the researchers would like to conduct an investigation for the language style in a movie through the conversation

\section{Methods}

This research is a qualitative design for research. According to [3], qualitative researchers are trying to understand the phenomenon by focussing on the entire picture rather than dividing it into variables. Accentuating qualitative research is descriptive text, according to Creswell, as quoted in Sihombing, namely a text that indicates how a person is or what is, and researchers use it to describe a subject when variables and theories are known $[18,20]$. The goal is not a numerical analysis, but a holistic picture and depth of 
understanding. Qualitative research was conducted in Spider-Man Far From Home to analyze the language types used in.

[14] said that the description of data is qualitative. One of the qualitative method characteristics is to see the process with which we must work according to the environment; the place where the research is conducted. There are seven types of qualitative research [3]. The studies include case studies, analyses of content or documents, ethnographical studies, theory studies, studies of history. Content or document analysis was used by researchers. The content or document analyses, according to [3], are research methods used for the identification of specific material characteristics for the purposes of written or visual materials. The analyzed material can be text books, newspapers, web pages, speeches, broadcasts, advertisements, musical compositions or any other kind of material. Because film was chosen by researchers as a research subject. As we know, the film has an analysable script.

\section{Data and Data Source}

The objective was to obtain data. The data are information or evidence used for discussing and deciding on the research questions [2]. The theme of the study is script film "Spider-Man Far From Home." The object of the investigation is the language style of all kinds based on the film by Joos. The investigators identified and analyzed the film in search of the types of home movie Spider-Man far. This film was directed by Chris McKenna and Erik Sommers and by Joh Watts. The film was downloaded from the responsible Internet download link, and the movie script was also downloaded from another trustworthy Internet download link. For some reasons, the film was chosen to be the data. First, several previous research has analyzed the types of language and the researchers found that Joos' theory is based on many types of language. Secondly, this film is a sort of super hero movies. The film tells the story of a spiderman, or Parker, whilst he is on a school trip to Europe, he's recruited to Nick Fury and Mysterio to face other threats. This movie was very interesting, could be seen from the jokes and moral value that can be taken from this movie. The last, the main character of this movie is Tom Holland or Spiderman. The researchers really liked this actor, both from his words, action and expressions that give when speaking to the other. The film premiered in Hollywood on June 26, 2019, and was released in the United States on July 2, 2019 in 3D and IMAX, and on July 3, 2019 in Indonesia, in 3D and IMAX.

\section{Technique of Data Collection}

Researchers classified five of them in [16], which discusses language style, based on the linguistic styles of [10]. In short, the methods are also followed in the analysis of the data:

1. Watching the Spider far from home movie to understand more what the story is about.

2. Searching the script of Spider far from home movie from the internet to get textual from of dialog [23]

3. Downloading the trans script and use of as a data research with utterances in the movie.

\section{Techniques of Data Analysis}

The data had been taken from Spider-script, man's far from home, and some measures have been taken to get the data:

1. Identifying the language style used in Spider-man far from home movie.

2. Classifying the types of language style used in Spider-man far from home movie using Joos theory.

3. Calculating the frequency of language style used in Spider-man far from home movie. 
4. Drawing the conclusion

\section{Results}

Here, the researchers presented two data as data analysis for analyzing the data in order to seek and find out the language styles used in the movie.

Data 1 (00:01:15)

Maria Hill : Nick, this was a tragedy, but it's not why we're here. What, are we fighting the weather now?

Nick Fury : Locals say the cyclone had a face.

Maria Hill : People say things when they're under stress. Okay, that does not mean that this is the start to another big world-

\section{Analysis Data 1}

The sentence above, the language is generally used in a formal situation. Formal conversations between Maria Hill she is agent in S.H.I.E.L.D and Nick Fury is leader S.H.I.E.L.D. This situations in movie is a village destroyed, their presence there was to find out what was really going on in the village. What the village to be destroyed. In conversation from Maria Hill say, "Nick, this was a tragedy", is defined as the style of language that used for serious situation . Nick gave an explanation to Maria based on local information about the fact situation in the village. This is a one way communication with little feedback and facts gleaned at the scene. Used a single topic oriented and it is related to the fact.

\section{Data 2 (00:03:08)}

Jason Ionello : Thanks to Kenneth Lim and Vihaan Ramamurthy for their help with that touching video tribute.

Betty Brant : This year has been nothing short of-

Jason Ionello : $S^{* *} t$ is crazy. It's like, insane.

Betty Brant : Jason.

Jason Ionello : What?

Betty Brant : No swearing.

Jason Ionello : Yeah, it's like the last day of school, we're good.

\section{Analysis Data 2}

Based on the dialogue above, Jason and Betty used casual language style. Jason and Betty is a student in the school, it shifts to show midtown school's news. Present about blip with the situation relaxed or normal in the school. In this dialogue Jason has produces slang language style, " $S^{* *} t$ is crazy." is means about Jason's frustration with the situation. Betty Brant use of the first nickname Jason when communication. Based on characteristic above the types of language style used in the dialogue is casual style because they are characteristic in accordance with the types of casual style.

Based on data analysis done, there are two results in this research: they are kinds of language used in the Spider-Man far from home movies and the most dominant types of language.

1. Types of language style used in Spider-Man Far From Home movie. 
The researchers found the language-type used in the 'Spider-Man: Far From Home' film from their research to answer the first research question. There were five kinds of language style that this film used based on Joos theory: it consists of two frozen data (6.6\%), formally three data (10\%), consultatively six (20\%), casually $11(36.7 \%)$ and intimately one data $(8 \%)$. (26,6 percent ).

The following tables are the result of data analysis that had been mentioned in the previous point above.

Table 1. Types of language styles in Spider-Man: Far From Home Movie.

\begin{tabular}{|c|c|c|c|}
\hline No & Types of language style & Total & Percentage \\
\hline 1 & Frozen & 2 & $6,7 \%$ \\
\hline 2 & Formal & 3 & $10 \%$ \\
\hline 3 & Consultative & 6 & $20 \%$ \\
\hline 4 & Casual & 11 & $36,7 \%$ \\
\hline 5 & Intimate & 8 & $26,6 \%$ \\
\hline & Total & 30 & $100 \%$ \\
\hline
\end{tabular}

2. The most dominant type of language is used in "Spiderman: Far From Home"

The most dominant types of language style in 'Spider-Man: Far from home' is a Casual Style, according to data from the scripts of text film founded. In conclusion, the dominant category in the film is casual, which has many casual characteristics, such as simple sentences, questions, opinions, remarks, sending and chatting. The situation of the casual in the film is relaxed or normal, which suits the conversation with a friend. In addition, the more detail of the language style is shown in the table above to clearly understand the data findings.

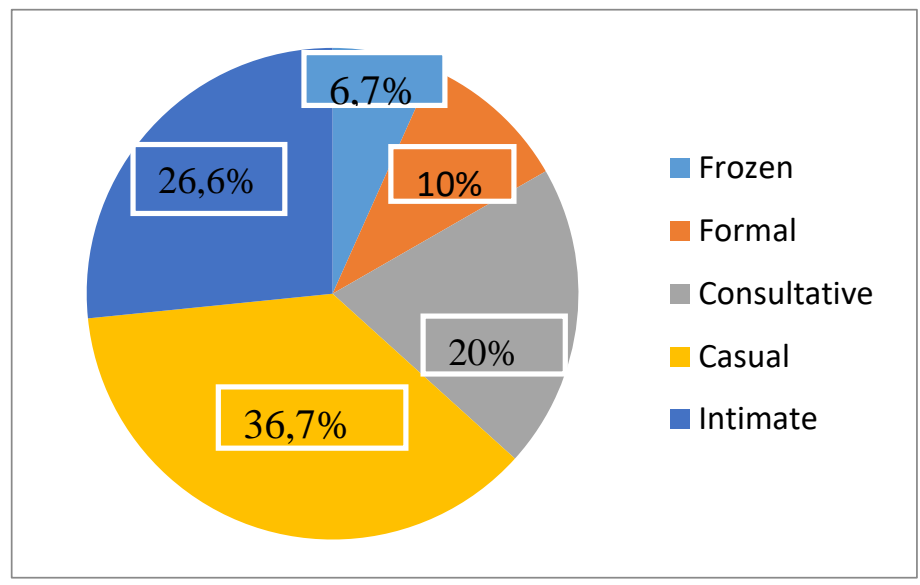

Figure 1. The dominant types of Language Style found in “Spider-Man: Far From Home” Movie.

\section{Discussion}

In this part of the discussion, the researchers discussed the question of the research in more detail. As we know, this study examines the type of language used by SpiderMan: Far From Home and the most dominant language used by all the movie characters. The researchers found 30 language-style data from Spider-Man: Far From Home movie as the basis of the explanations for this discussion. The researchers debated the first question in the first section, what linguistic styles Spider-Man uses: Far From Home. Another question, which language style is most commonly used in Spider-Man, was discussed by researchers. 
Spider-Man: Far From Home is a film about the super hero. The film contains some kinds of style used for all characters when this research is discussed. The researchers discussed all the data after analyzing the data to answer the question of the research. The researchers used the theory of Joos. Joos classified five language styles based on theory. It is frozen, formal, consulting, casual and intimate. It is intimate. The researchers classified the creative language style, which is commonly applied in daily conversations on the basis of the situation or background. Language style in society is commonly used daily.

This study is supported in the previous study by reference. This study is comparable and similar to the previous study. The preceding study was by Rahardian (2016) who carried out a research titled "A linguistic analysis in the film "Fury'.' This research is designed to analyze the style of language used in the film "Fury" by all characters. The research aims were to determine (1) what language type the movie used; (2) which types of language were the most commonly used in the film. In the preceding study, Joos's theory analyzed the language style that was also applied for this research using the qualitative methodology. The difference between the described studies and the study, by contrast, lies in the fact that, in the previous studies, five types were not developed based upon Joos' theory.

\section{Conclusions}

The focus of this study is based on the research problem and the type of language found. The conclusion is also based on the summary of the data analysis from the previous Chapter in Data Analysis. The writing tried to find words related to language style during the analysis of the data. This results in frozen, formal, consultative, casual or intimate analyses of language types.

Spider-man has five kinds of language: far from home, they are: frozen style 2 data (6.6\%), 3 formal data (10\%), 6 formal data (20\%), 11 data formal style (36.7\%) and eighth style format data format (26,6 percent). Spiderman: Far From Home movie is casual. The most dominant language type found in Spider-Man. The theory of Joos consists of five language styles. There are types of functional differences based on the film, for example, the actor frozen uses the formal situation and requires no response, formal styles used to formalize the situation behind the scenes, semi-formal, casual situations used for relaxing the communication, and the last intimate to talk to family in the film.

Based on the above findings and discussions, the researchers found that "Spider-Man: Far From Home" film contains all the types of frozen, formal, consultative, casual and intimate theory of Joo's language style. The investigators found 30 data from the movie "Spiderman: Far From Home" script in the research finding. The dominant type of this research is casual, as spiderman film is an action film. The actor in this film are young people, so that the language is relaxed and straightforward. Peter called his friend "men," for instance. The final position is Frozen style because it is in legal situations and formal ceremonies the most formal and elegant style. The use of frozen styles such as state ceremonial speeches in government palaces and church sermons.

Conflicts of Interest: “The authors declare no conflict of interest."

\section{References}


[1] Abidin, R. R. (2018). A Study of Language Style Used by Characters in Frozen Movie. Skripsi. Surabaya: Faculty of Arts and Humanities, The Islamic University Sunan Ampel. Retrieved http://digilib.uinsby.ac.id/26256/7/Rhike\%20Resty\%20Abidin_A73214054.pdf

[2] Arikunto, S. (2010). Prosedur Penelitian Suatu Pendekatan Praktik. Jakarta: Rineka Cipta

[3] Ary, D., Jacobs. L.C., Sorensen, C. (2010). Introduction to Research in Education (8thEd.). California: Wadsworth

[4] Batubara, A. K. S., Manurung, V. L., Simanjuntak, N. S. U., and Herman. (2021). Analysis on Aspects of Educational Values Found in an Indian Movie. Central Asian Journal Of Social Sciences And History (CAJSSH), Vol. 2, Issue 8, ISSN: 2660-6836, PP. 0416. Retrieved from: https://cajssh.centralasianstudies.org/index.php/CAJSSH/article/view/141

[5] Ducrot and Todorov. (1993). Introduction to Language Style. London: Cambridge University

[6] Goldstein, Bruce E. (2008). Understanding Morphology. London: Hodder Education and Hachette UK Company.

[7] Herman, Sinurat, B., and Sitio, I. T. (2019). Ethnography of Communication Analysis in the Short Story of Romeo and Juliet. International Technology and Science Publications (ITS) Education Journal Volume 2, 2019. ISSN: 2617-4588, DOI: 10.31058/j.edu.2019.23002, page 41-50. Retrieved from http://www.itspoa.com/itsadmin/Ll/LL.DE.asp?action=Paper_Information\&id=1785\&at=Ethnography\%20of\%20Communication\%20Analysis\%20in \%20the \%20Short \%20Story \%20of $\% 20$ Romeo\%20and\%20Juliet\&jn=Education\%20Journal

[8] Herman. (2017). Shift in Translation from English into Indonesia on Narrative Text. International Journal of European Studies. Vol. 1, No. 3, 2017, pp. 72-77. doi: 10.11648/j.ijes.20170103.12. Retrieved from http://www.sciencepublishinggroup.com/journal/paperinfo?journalid=520\&doi=10.11648/j.ijes.20170103.11

[9] Holmes, J. (2013). An Introduction to Sociolinguistics. 3rd ed. Harlow: Pearson Education Limited.

[10] Joos, M. (1976). The Style of Five Clocks Ed. Nancy AinsWorth Johnson, current. Topics in Language: Introductory Reading. Messachusetts...Rahardian (2016).

[11] Meyerhoff, M. (2006). Introducing Sociolinguistics. New York: Routledge.

[12] Mappiasse, S. and Johari, A, (2014). Evaluation of English as a foreign language and its curriculum in Indonesia: A review. English language teaching. Faculty of education, 7(10), 113-122

[13] Nainggolan, F., Siahaan, D. A., Sinurat, B., and Herman. (2021). An Analysis of Figurative Language on Joe Biden's Victory Speech. International Journal on Integrated Education, Vol. 4 No. 3 (2021), PP. 364-375, DOI: https://doi.org/10.31149/ijie.v4i3.1514. Retrieved from: https:/journals.researchparks.org/index.php/IJIE/article/view/1514

[14] Purba, R. and Herman. (2020). Multimodal Analysis on Ertiga Car Advertisement. Wiralodra English Journal (WEJ), Vol 4 No 1 Maret 2020, PP. 21-32. Retrieved from http://wej.unwir.ac.id/index.php/wej/article/view/77

[15] Purba, D., Sulistia, F., Manurung, V. L. B., \& Herman. (2021). Sociolinguistics Analysis on Language Style Form at the Movie Script of Papillon. Universal Journal of Social Sciences and Humanities, 1(1), 37-45. DOI: 10.31586/ujssh.2021.110. Retrieved from https://www.scipublications.com/journal/index.php/ujssh/article/view/110

[16] Rahardian. (2016). An Analysis of Language style in "Fury" Movie. Student of Faculty of Letters and Humanities, the State Islamic University Sunan Ampel Surabaya.

[17] Raharjo, Y. (2017). Language Style Used in LINE Conversation. Unpublished: State Islamic University of Sunan Ampel Surabaya.

[18] Sihombing, P. S. R. (2020). Male And Female Strategy In Reading Comprehension Of Narrative Text At SMA Kampus FKIP Universitas HKBP Nommensen Pematangsiantar. International Journal of English, Literature and Social Sciences (IJELS), Vol 5 No 1

[19] Situmorang, R. K. and Herman. (2021). An Analysis of Slang Language Styles Used in Charlie's Angels Movie. Journal of English Educational Study (JEES), Vol. 4, No. 1, PP. 21-29. DOI: https://doi.org/10.31932/jees.v4i1.820. Retrieved from: http://jurnal.stkippersada.ac.id/jurnal/index.php/JEES/article/view/820

[20] Van Thao, N., Sinaga, M. R., and Herman. (2021). Semantic Analysis of Contextual Meaning in Dialogue of "The Ugly Duckling" Short Story. Walailak Journal of Social Science, Vol. 14 No. 2 (2021): March - April, E-ISSN: 2697-6390. Retrieved from: https://so06.tci-thaijo.org/index.php/wjss/article/view/239940

[21] Wardhaugh, R. (2010). An Introduction To Sociolinguistics, Sixth Edition. West Sussex: Blackwell Publishing Ltd.

[22] Wong, Lilian L.C \& Nunan, D. (2011), The Learning Style and Strategies of Effective Language Learners, Elsvier Hongkong: Hongkong University Press

[23] https://transcripts.fandom.com/wiki/Spider-Man:_Far_From_Home 